\title{
GEOLOGI DAN KARAKTERISTIK BIJIH PIT RAMBA JORING DEPOSIT MARTABE, SUMATERA UTARA
}

\section{GEOLOGY AND ORE CHARACTERISTIC OF RAMBA JORING PIT MARTABE DEPOSIT, NORTH SUMATRA}

\author{
Asri Arifin, Mega Fatimah Rosana, Euis Tintin Yuningsih, dan Boy Yoseph CSSSA \\ Fakultas Teknik Geologi Universitas Padjadjaran, Bandung \\ asri15008@mail.unpad.ac.id
}

\section{ABSTRAK}

Deposit Ramba Joring merupakan bagian dari wilayah Kontrak Karya (KK) pertambangan umum PT Agincourt Resources yang terletak di Kelurahan Aek Pining, Kecamatan Batangtoru, Kabupaten Tapanuli Selatan, Provinsi Sumatera Utara. Penelitian ini bertujuan untuk mengetahui kondisi geologi meliputi geomorfologi, stratigrafi dan struktur geologi serta karakteristik bijih yang mengandung emas-perak pada deposit Ramba Joring. Penelitian dilakukan pada 44 lubang bor dan 15 conto permukaan. Penelitian menggunakan metode analisis petrografi sayatan tipis dan poles, Analytical Spectral Devices (ASD), Scanning Electron Microscopy with Energy Dispersive (SEM EDS) serta pengolahan statistik data geokimia assay berupa nilai kadar kandungan $\mathrm{Au}, \mathrm{Ag}, \mathrm{Cu}, \mathrm{SxS}$ (sulfide sulphur) yang didapatkan melalui analisis Atomic Absoption Spectrometry (AAS). Daerah penelitian tersusun oleh litologi, diurutkan dari tua ke muda, berupa satuan andesit hornblende dan breksi polimikmonomik. Satuan batuan andesit hornblende dan breksi polimik-monomik teralterasi kuat oleh

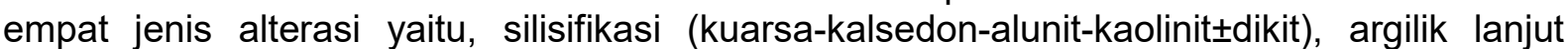

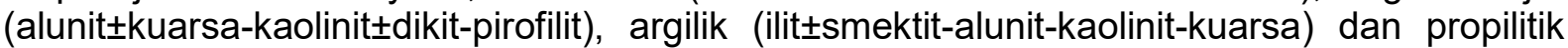
(klorit-epidot-kalsit). Terdapat enam jenis mineral sulfida pada daerah penelitian, paragenesa dimulai dari pirit, enargit, tennantit, tetrahedrit dan kovelit bersamaan dengan pengendapan emas-perak serta pirit dengan kristal berbentuk sempurna yang terbentuk paling akhir. Hasil uji pada data assay geokimia menunjukkan adanya korelasi antara kandungan unsur $\mathrm{Au}, \mathrm{Ag}$, Cu dan SxS (sulfide sulphur) terhadap jenis alterasi. Diketahui bahwa mineralisasi emas dan logam lainnya berasosiasiasi dengan mineral sulfida yang melimpah pada alterasi silisifikasi namun semakin berkurang pada jenis alterasi argilik hingga menghilang pada alterasi propilitik.

Kata kunci: Martabe, Sulfidasi Tinggi, Paragenesis Sulfida, Scanning Electron Microscopy with Energy Dispersive (SEM EDS), Analytical Spectral Devices (ASD)

\section{ABSTRACT}

Ramba Joring deposit is located in Aek Pining Village, Batangtoru Sub-district, South Tapanuli Regency, North Sumatra, in the Contract of Work (CoW) area which belongs to PT Agincourt Resources. The study aimed to understand the geology, including geomorphology, stratigraphy, structural geology and ore characteristic contain gold- silver of Ramba Joring deposit. The study was conducted on 44 drill holes and 15 surface samples. This research used petrographic analysis on both thin and polished section, Analytical Spectral Devices (ASD), Scanning Electron Microscopy with Energy Dispersive (SEM EDS) and statistical data processing of geochemical assay of $\mathrm{Au}, \mathrm{Ag}, \mathrm{Cu}, \mathrm{S} x \mathrm{~S}$ (sulfide sulphur) concentration derived from Atomic Absorption Spectrometry (AAS). The study area consist two lithologic units, from oldest to youngest, hornblende andesite unit, and polymict-monomict breccia unit. The hornblende andesite and polymict-monomict breccia rock unit is pervasively altered by four types of alterations; silicification (quartz-chalchedony-alunite-kaolinite $\pm d i c k i t e), ~ a d v a n c e d$

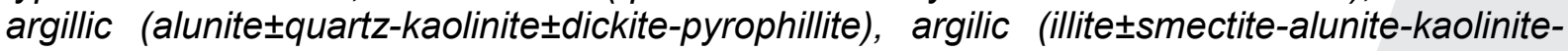


quartz) and propilitic (chlorite-epidote-calcite). There are six types of sulphide minerals in the study area, the paragenesis sorted from earlier to the latest formed, are pyrite, enargite, tennantite, tetrahedrite, covellite along with the deposition of gold-silver and well crystallize pyrite. The test results on geochemical assay data showed a correlation between $\mathrm{Au}, \mathrm{Ag}, \mathrm{Cu}$ and SxS (sulfide sulphur) content on alteration types. It is known that gold and other metals associated with abundant sulfide minerals in silicification alteration but decreased in argillic and then disappear to propylitic alteration types.

Keywords: Martabe, High sulphidation, Sulfide Paragenesis, Scanning Electron Microscopy with Energy Dispersive (SEM EDS), Analytical Spectral Devices (ASD).

\section{PENDAHULUAN}

Daerah pertambangan PT Agincourt Resources (Martabe) terletak pada Busur Vulkanik Sumatera berumur Kenozoikum yang perpanjangannya membentuk Busur Sunda-Banda di sebelah baratlaut sepanjang $1.600 \mathrm{~km}$. Zona subduksi di sekitar Lempeng Samudera Hindia sepanjang busur tersebut mempengaruhi terbentuknya sesar regional, aktifitas seismik dan aktifitas vulkanik lainnya. Sistem Sesar Sumatera (Sumatran Fault System) membentang sepanjang Pulau Sumatera dan berada kurang lebih $10 \mathrm{~km}$ dari wilayah Martabe, di sebelah timur membentuk pull a part graben yang terisi oleh endapan volkano-sedimen terlitifikasi yang terdiri dari lapisan batupasir, batulanau, batulempung karbonan serta aliran lava andesitik (Sutopo et al, 2013) Aktifitas tektonik diperkirakan merupakan penyebab terbentuknya endapan hidrotermal, multi phase magmatic, pembentukan breksi freatik dan freatomagmatik serta deposit emas Martabe. Deposit emas Martabe sebagian besar terletak pada bagian atas dari kubah porfiri dasit-andesit serta kompleks diatreme dan kontak dengan endapan volkanosedimen di bagian timur hingga selatan wilayah pertambangan Martabe.

Deposit Ramba Joring merupakan salah satu deposit pada wilayah pertambangan Martabe. Litologi yang ditemukan pada deposit ini terdiri dari satuan andesit hornblende dengan keterdapatan urat kuarsa secara setempat-setempat dan satuan batuan breksi polimik-monomik.
Alterasi di daerah penelitian dibagi menjadi 4 zona berdasarkan karakteristik alterasi yang diketahui dari analisis tekstur batuan, pengamatan petrografi serta analisis $A S D$. Zona alterasi dicirikan dengan tekstur breksisasi dan silika masif diikuti dengan tekstur vuggy-residual quartz di bagian luar dari zona silisifikasi, zona argilik lanjut ditandai dengan kehadiran mineral kuarsadikit-kaolinit yang dikelilingi oleh zona argilik dengan kelimpahan mineral ilit-smektit dan di bagian luar terdapat zona propilitik yang dicirikan dengan kehadiran mineral kloritsmektit-karbonat. Mineralisasi pada deposit Ramba Joring mengalami perubahan seiring dengan pertambahan kedalaman begitu juga dengan tingkat oksidasi yang secara signifikan mengalami perubahan. Zona oksidasi dan transisi mineralisasi mengalami perubahan menjadi mineralisasi sulfida terdiri dari mineral enargit-luzonitkovelit-pirit yang ditemukan pada urat kuarsa dan open spaces/vug pada deposit Ramba Joring. Berdasarkan studi oleh Sutopo et al, (2013) alterasi dan mineralisasi yang berlangsung berumur 2,0 s.d. 3,3 Ma berdasarkan dating radioaktif unsur $\mathrm{K}-\mathrm{Ar}$ pada mineral alunit hipogen.

Penelitian ini bertujuan untuk mengetahui kondisi geologi dan menentukan karakteristik bijih yang berasal dari deposit Ramba Joring. Penelitian ini dilakukan pada deposit Pit dengan skala 1: 10.000 . Pemetaan geologi dilakukan untuk mengetahui kondisi geologi permukaan daerah penelitian. Logging batuan dilakukan pada conto batuan inti yang berasal dari pengeboran diamond core. 


\section{LOKASI PENELITIAN}

Tambang emas Martabe berada di bagian selatan Provinsi Sumatera Utara, terletak pada Kecamatan Batangtoru, Tapanuli Selatan (Gambar 1). Tambang emas ini memiliki beberapa deposit, salah satunya adalah deposit Ramba Joring yang mulai ditambang sejak awal 2018. Deposit ini memiliki tipe epitermal sulfidasi tinggi (Sutopo et al, 2013) dengan tubuh mineralisasi berbentuk sub-vertikal dan berasosiasi dengan batuan breksi freatikfreatomagmatik sepanjang patahan yang berarah relatif utara sampai timurlaut.

\section{METODE PENELITIAN}

Penelitian dilakukan dengan pengambilan conto permukaan dan bawah permukaan. Conto permukaan berukuran hand specimen dikumpulkan melalui pemetaan lapangan, sedangkan conto bawah permukaan diambil dari 44 titik bor dan sebanyak 17 conto permukaan pada elevasi yang berbeda-beda. Analisis geokimia menggunakan metode Atomic Absorption Spectrometry dilakukan pada keseluruhan conto, pengujian dilakukan oleh Intertek dan SGS Laboratory sedangkan analisis petrografi dan mineragrafi dilakukan pada Laboratorium Tekmira dan Laboratorium Universitas Padjadjaran, analisis $A S D$ dilakukan pada Laboratorium Departemen
Eksplorasi PT Agincourt Resources sedangkan analisis SEM EDS Mapping dilakukan pada Laboratorium Tekmira untuk sejumlah conto batuan terpilih dengan karakteristik litologi dan alterasi yang berbeda-beda

\section{HASIL DAN PEMBAHASAN}

\section{Geomorfologi Daerah Penelitian}

Analisis terhadap geomorfologi daerah penelitian dengan memperhatikan morfologi khas dan kontur daerah penelitian. Geomorfologi Pit Ramba Joring dicirikan dengan ketinggian yang relatif curam yaitu sekitar 670 meter s.d. 680 meter di atas permukaan laut dengan pola perbukitan yang memanjang ke arah utara - utara timurlaut. Morfologi Ramba Joring ditandai dengan ketinggian puncak yang tidak teratur dan relatif sirkular yang relatif lebih rendah daripada kedua puncak yang berada di bagian utara dan selatan barat daya, selain itu morfologi deposit Ramba Joring dengan topografi yang lebih tinggi daripada area di sekitarnya mengindikasikan bahwa daerah penelitian termasuk kedalam suatu perbukitan intrusi, kontrol struktur yang kuat berarah relatif utarabaratlaut memisahkan daerah penelitian yang terjal dengan bagian depresi yang lebih rendah di sebelah barat daerah penelitian.

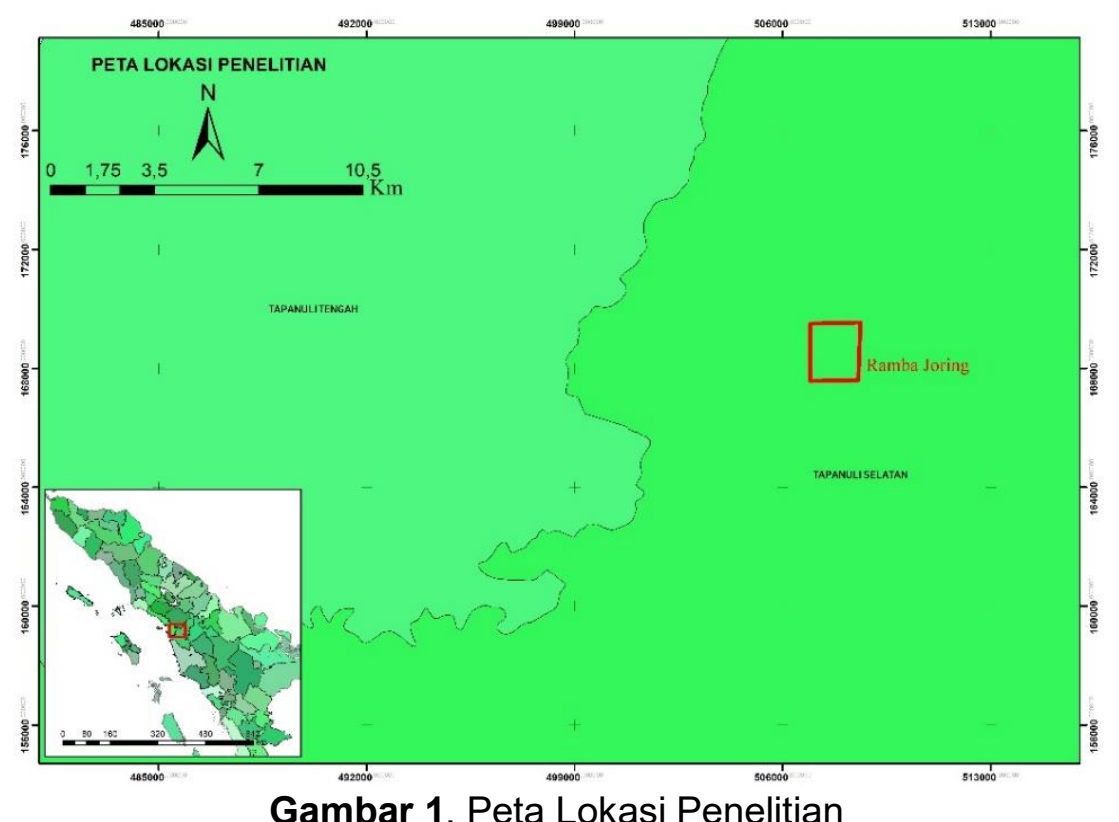


Analisis geomorfologi dengan persentase kelerengan menunjukkan bahwa pada bagian timur hingga utara daerah penelitian memiliki persen kelerengan rata-rata sebesar $18 \%$, pada bagian selatan rata-rata sebesar $13 \%$ dan pada bagian barat memiliki persen kelerengan rata-rata sebesar $5 \%-7 \%$, yang menunjukkan bahwa daerah paling utara merupakan daerah yang lebih tinggi dan relatif curam. Pola aliran sungai sebagian besar menunjukkan pola rectangular hingga trellis. Berdasarkan pada analisis terhadap unsur-unsur geomorfologi, daerah penelitian termasuk ke dalam bentang alam struktural-denudasional.

\section{Struktur Geologi Daerah Penelitian}

Indikasi struktur geologi dapat dilihat dari foto udara, citra satelit, hasil pengukuran dan pengamatan lapangan. Struktur regional yang berkembang di Pulau Sumatera mempengaruhi struktur lokal di daerah penelitian (Davies, 2002). Terdapat dua arah orientasi struktur yang bekerja khususnya pada deposit Pit Ramba Joring, struktur berorientasi relatif utara sampai timurlaut - selatan baratdaya dan struktur yang berarah utara hingga baratlaut tenggara. Struktur dengan arah orientasi utara hingga timurlaut merupakan perpanjangan dari struktur yang bekerja pada area lain di wilayah Tambang Emas Martabe, dengan pengayaan mineralisasi searah dengan struktur yang berorientasi arah ini. Struktur dengan arah orientasi utara sampai baratlaut hingga tenggara searah dengan struktur regional Pulau Sumatera. Meski kandungan mineralisasi tidak sebanyak dengan struktur utara sampai timurlaut, namun struktur ini memisahkan area termineralisasi dengan area yang tidak termineralisasi. Topografi daerah penelitian menunjukkan bahwa kontrol struktur ini memisahkan Pit Ramba Joring dengan graben di sisi sebelah barat dan lembah di sebelah utara daerah penelitian.

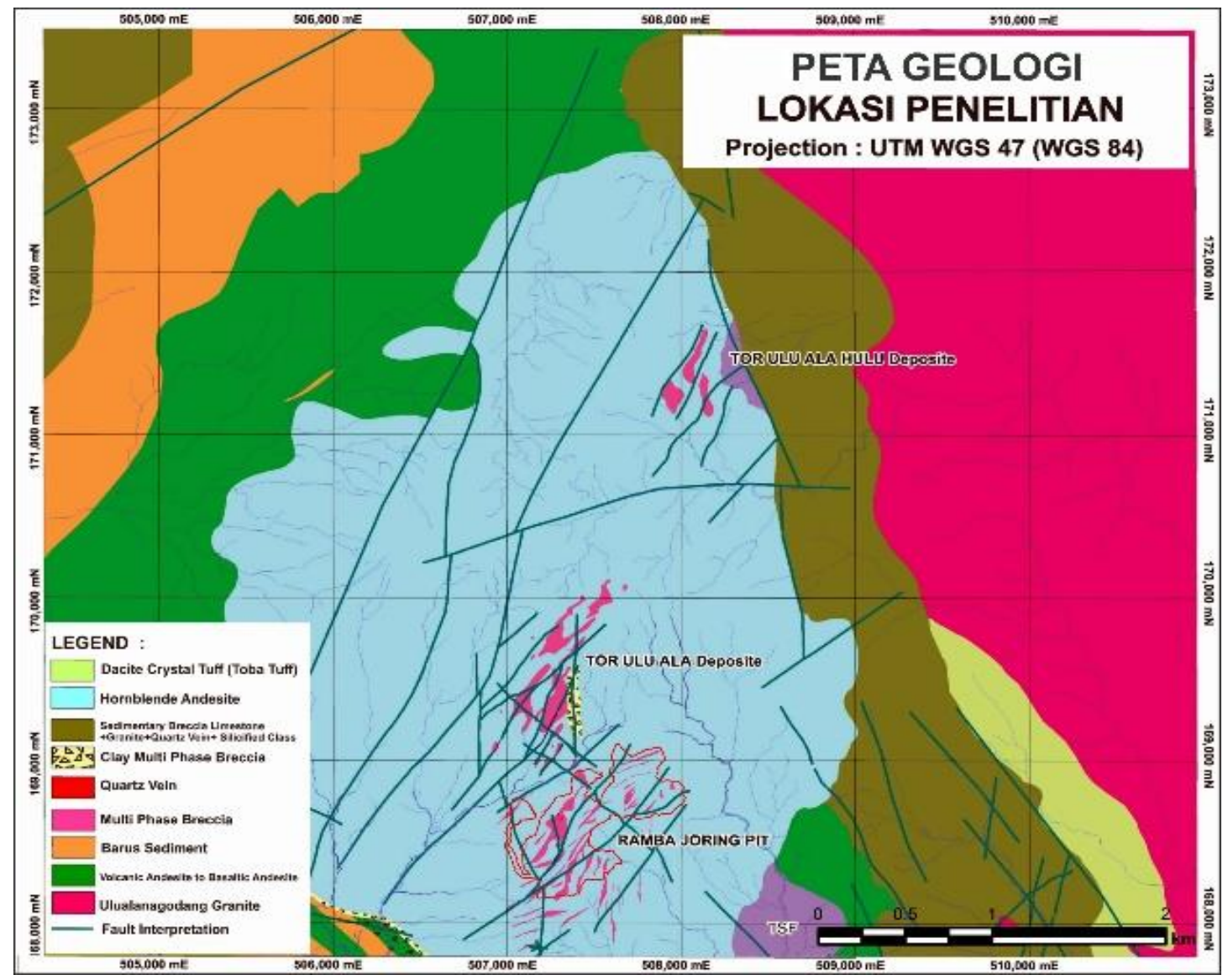

Gambar 2. Peta geologi tambang emas Martabe dengan interpretasi struktur oleh PT Agincourt 2017 (dimodifikasi dari Apsden et al, 1982a; 2002) 


\section{Stratigrafi Daerah Penelitian}

Satuan batuan yang terdapat di daerah penelitian didominasi oleh batuan andesit hornblende yang tersebar hampir meliputi 60 persen daerah penelitian, setempatsetempat di jumpai batuan breksi polimikmonomik yang terhampar pada arah utara utara timurlaut mengikuti struktur yang berkembang di daerah penelitian (Gambar 2). Penentuan jenis batuan dilakukan berdasarkan pengamatan secara makroskopis didukung dengan pengamatan petrografis sayatan tipis pada beberapa conto batuan inti dan conto hand specimen.

Batuan andesit hornblende, secara mikroskopik umumnya memiliki warna abuabu putih/kehijauan - abu-abu kekuningan, tekstur porfiritik, inequigranular, allotriomorfik-hipidiomorfik. Batuan tersusun atas mineral plagioklas $( \pm 20 \%)$, mineral hornblende (< 10\%), kuarsa sekunder (< $5 \%$ ) dengan bentuk kristal granular dan membentuk struktur mosaic serta massa dasar batuan yang terdiri atas mineral dengan ukuran yang halus (> 60\%). Sebagian besar mineral-mineral yang terdapat pada massa batuan telah mengalami ubahan sedang hingga ubahan kuat, setempat-setempat juga ditemukan batuan dengan urat kuarsa dan sebagian kalsedon dengan tekstur colloformcrustiform serta massive banded. Batuan breksi polimik-monomik memiliki warna abuabu hingga kekuningan/kecoklatan memiliki umur lebih muda daripada batuan andesit hornblende. Hal ini diketahui dari matrik batuan breksi yang sebagian merupakan batuan andesit hornblende, batulanau dan batulempung tersilisifikasi kuat. Fragmen batuan berukuran antara $0,5 \mathrm{~mm}$ s.d. $70 \mathrm{~cm}$, bentuk relatif menyudut, dijumpai tekstur wispy. Matriks berupa pasiran halus dengan kemas terbuka, sortasi buruk dan mengalami ubahan kuat.

Berdasarkan Sutopo (2013), satuan andesit hornblende disebandingkan dengan satuan andesit hornblende (Tpia), yang merupakan bagian dari kompleks dome/intrusi Martabe (Gambar 3). Satuan ini terbentuk akibat intrusi dari tubuh magma dengan komposisi andesitik yang kemudian diterobos oleh satuan breksi polimik-monomik freatikfreatomagmatik. Sedangkan batuan breksi polimik-monomik ini termasuk ke dalam multiphase breccia freatik-freatomagmatik dengan umur yang relatif lebih muda daripada satuan batuan andesit hornblende.

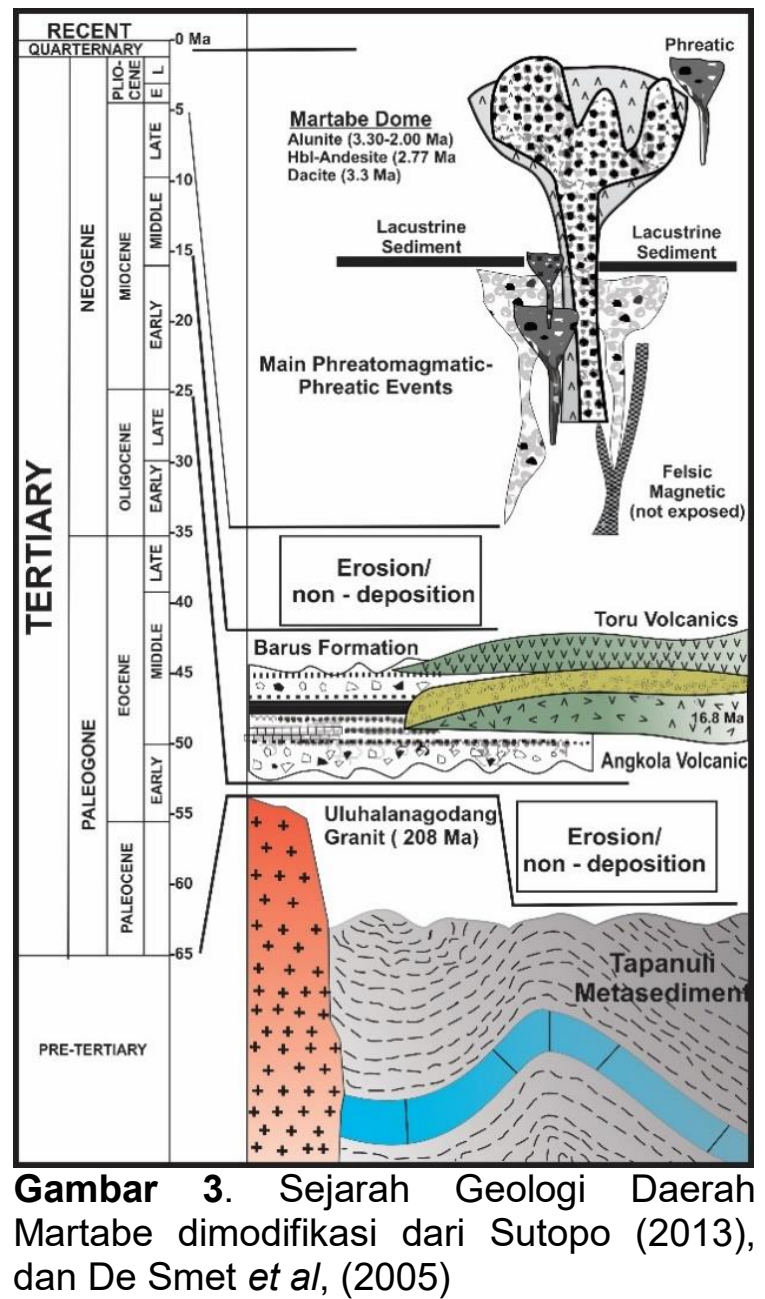

\section{Zonasi Alterasi Daerah Penelitian}

Zona alterasi yang berkembang pada daerah penelitian (Gambar 4) berupa alterasi silisifikasi yang terdapat di bagian tengah dari zona ubahan dengan tekstur masif dan brecciated yang mengalami silisifikasi kuat. Mineral yang umum didapatkan adalah mineral kuarsakalsedon-alunit dengan kelimpahan mineral sulfida. Di bagian luar dari zona silisifikasi terdapat zona alterasi argilik lanjut dengan kehadiran mineral kuarsa-alunit, kuarsa-dikit dan kuarsa-kaolinit \pm dikit dengan tekstur 
vuggy yang secara gradual berubah menjadi tekstur residual yang dikelilingi oleh kumpulan mineral kuarsa-ilit-smektit yang merupakan zona argilik di bagian luar dari argilik lanjut. Zona alterasi yang terdapat pada bagian luar dari zona ubahan ini adalah zona alterasi propilitik dengan kehadiran kelompok mineral klorit+smektit+ epidot+karbonat (Gambar 5).

Beberapa mineral ubahan yang terdapat pada daerah penelitian berdasarkan analisis petrografi, $A S D$ dan SEM-EDS, antara lain:

- Mineral kuarsa, opal dan kalsedon Mineral kuarsa yang terdapat di daerah penelitian merupakan mineral kuarsa sekunder yang terbentuk pada temperatur dan $\mathrm{pH}$ rendah (Stoffregen, 1987). Kuarsa banyak terdapat pada alterasi silisifikasi dan argilik lanjut. Opal terbentuk pada temperatur rendah kurang dari $100{ }^{\circ} \mathrm{C}$ pada fluida yang kaya silika dengan $p H$ rendah hingga hampir netral (Corbett dan Leach, 1998), umum dijumpai di sekitar daerah hot spring namun tetap dapat terbentuk pada semua kondisi geologi (Hedenquist et al, 1998). Kalsedon terbentuk pada kondisi yang jenuh dengan silika pada temperatur $100^{\circ} \mathrm{C}$ s.d. $200{ }^{\circ} \mathrm{C}$ (Henley, 1983), terdapat pada alterasi silisifikasi pada vein atau veinlets.

\section{- Mineral alunit}

Terbentuk pada kondisi steam-heated sebagai akibat dari oksidasi larutan asam sulfat dengan $p H$ rendah membentuk alunit dengan bentuk pseudo cubic dan tabular. Alunit terisi pada rekahan, mengganti fragmen dan matrik batuan atau lubang vug pada batuan. Alunit ditemukan pada alterasi silisifikasi, namun melimpah pada alterasi argilik lanjut.

- Mineral kaolinit \pm dikit dan pirofilit Terbentuk pada $\mathrm{pH}$ rendah $(p H<4)$ biasa dijumpai bersama dengan alunit pada $\mathrm{pH}$ 3-4. Kaolinit \pm dikit terbentuk pada kedalaman yang relatif dangkal yaitu pada kedalaman 0-300 m dengan temperatur $<150^{\circ} \mathrm{C}-200^{\circ} \mathrm{C}$ sedangkan pirofilit terbentuk pada temperatur yang lebih tinggi yaitu $200^{\circ} \mathrm{C}$ s.d. $250^{\circ} \mathrm{C}$ dan pada kedalaman yang tinggi, akan tetapi pada kondisi konsentrasi silika melebihi kelarutan kuarsa, pirofilit dapat terbentuk pada temperatur yang lebih rendah dari $150{ }^{\circ} \mathrm{C}$. Mineral kaolinit \pm dikit dan pirofilit terdapat pada alterasi argilik lanjut dan kadang dijumpai sebagai patches pada alterasi silisifikasi yang mengindikasikan adanya zona lokal yang memiliki permeabilitas rendah yang terhindar dari proses pencucian oleh larutan asam (Pirajno, 2009).

\section{- Mineral ilit-smektit}

Terbentuk pada $\mathrm{pH}$ 4-6, pada $\mathrm{pH} 5$ sering berasosiasi dengan kaolinit (Pirajno, 2009). Ilit terbentuk pada temperatur $200{ }^{\circ} \mathrm{C}$ s.d. $250{ }^{\circ} \mathrm{C}$, sedangkan smektit terbentuk pada temperatur $<100^{\circ} \mathrm{C}$ s.d. $150^{\circ} \mathrm{C}$, kedua jenis mineral terdapat pada jenis alterasi argilik, akan tetapi smektit lebih banyak terdapat pada alterasi argilik bertemperatur rendah (Thompson et al, 1996), kedua mineral juga terdapat dalam jenis alterasi argilik lanjut dengan persentase yang lebih sedikit.

- Kelompok mineral klorit-ilit-epidotkarbonat

Terbentuk pada $p H$ 5-6 mendekati netral, klorit berasosiasi dengan kelompok mineral ilit-smektit dan karbonat pada kedalaman sekitar $300 \mathrm{~m}$ s.d. $800 \mathrm{~m}$ dengan temperatur pembentukan yang lebih rendah. Mineral epidot dan karbonat mengindikasikan komposisi fluida yang lebih netral hingga basa serta rendahnya kandungan gas $\mathrm{CO}$ dalam fluida selama proses pemanasan (Hedenquist et al, 1998). 


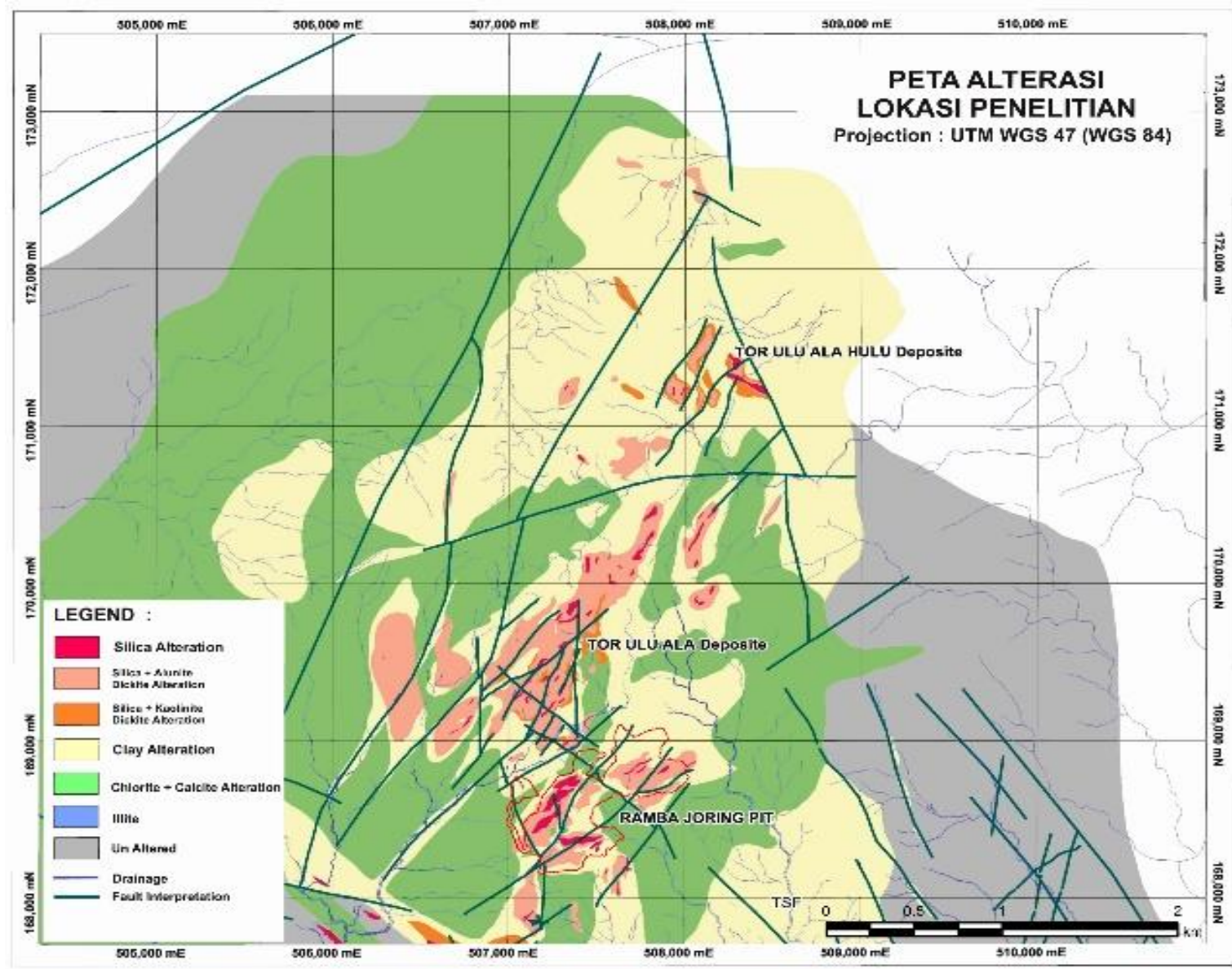

Gambar 4. Peta zonasi alterasi Tambang Emas Martabe dan daerah penelitian (dimodifikasi dari Apsden et al, 1982a; 2002 dan diupdate oleh PT Agincourt Resources, 2017)

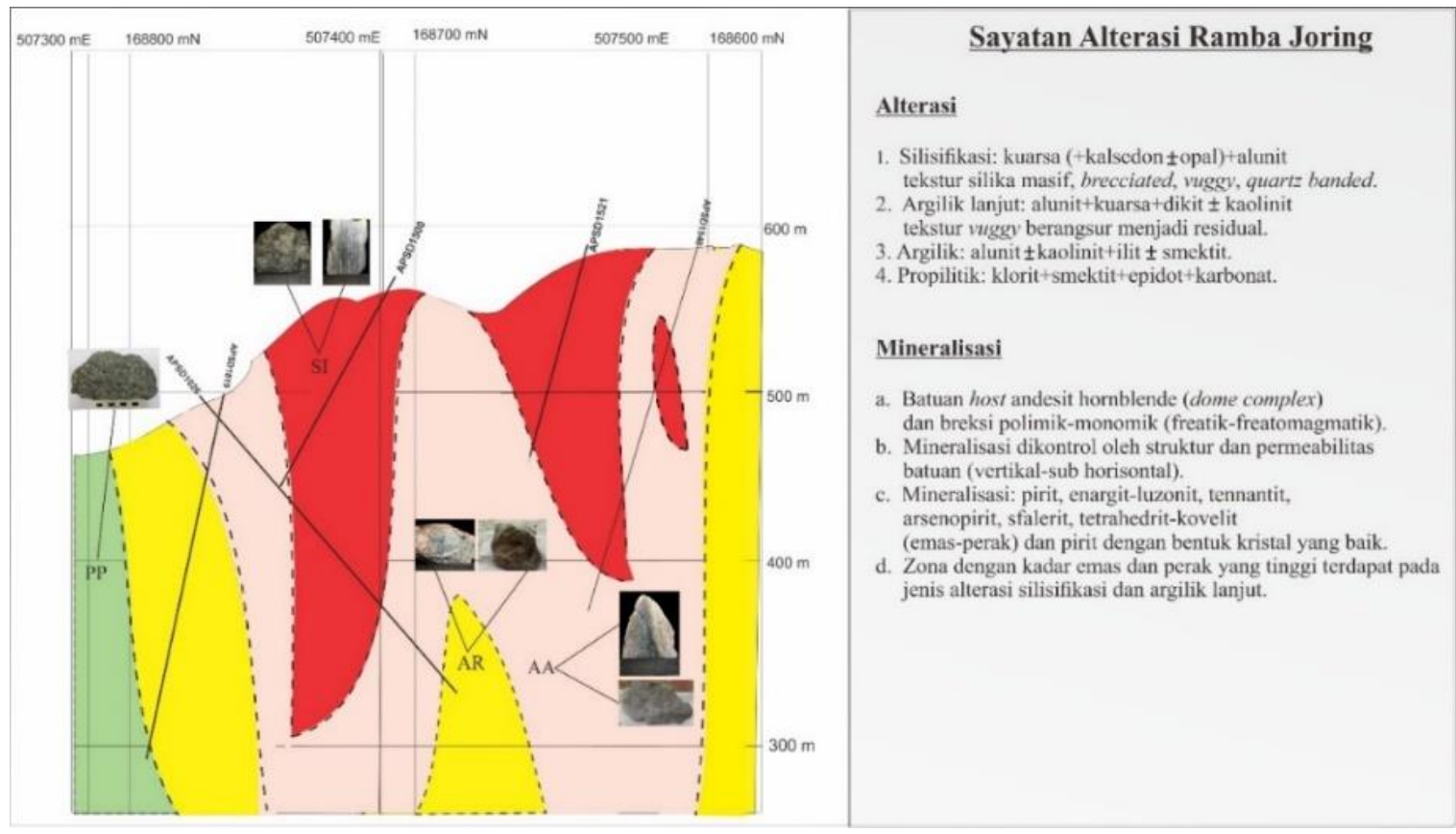

Gambar 5. Model alterasi daerah penelitian berdasarkan interpretasi batuan inti menurut konsep epitermal sulfida tinggi oleh Hedenquist et.al,(1998) 


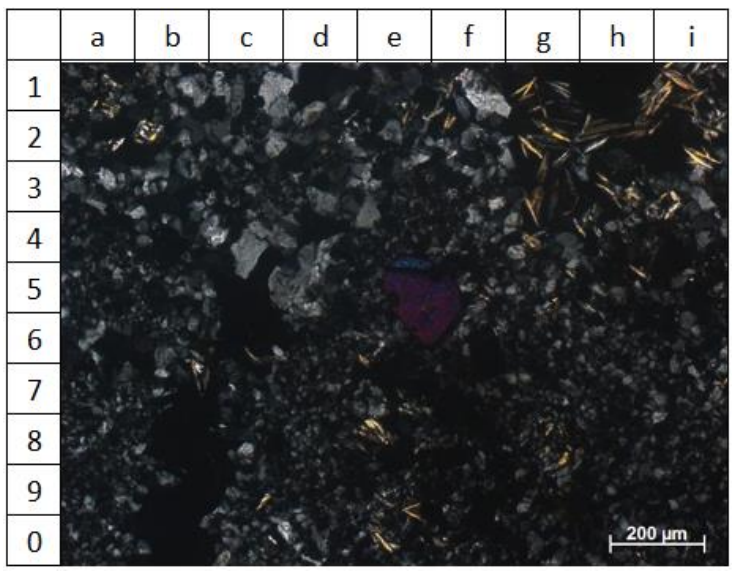

Gambar 6. Fotomikrograf sayatan tipis dengan perbesaran $200 \mu \mathrm{m}$

Ket.: alunit $=\mathrm{g} 1-\mathrm{g} 2$, mineral opak $=\mathrm{b} 8-\mathrm{b} 9$, kuarsa $=\mathrm{c} 1-$ $\mathrm{c} 2$, rutil $=\mathrm{e} 5$, mineral oksida besi $=\mathrm{g} 9$.

Sayatan batuan pada Gambar 6 berasal dari titik bor APSD 1031 dengan kedalaman $50,8 \mathrm{~m}$ s.d. $51,8 \mathrm{~m}$ dan sayatan batuan (Gambar 7) berasal dari titik bor APSD 1550 dengan kedalaman 63,1 m s.d. $64 \mathrm{~m}$, ditempati batuan andesitik hornblende dengan kehadiran mineral kuarsa sekunder bertekstur mosaic yang terlihat mengisi rekahan sedangkan mineral alunit berbentuk tabular menjarum tersebar di tubuh batuan, terkadang dijumpai pada bagian tepi dari suatu mineral lempung atau pada bagian luar suatu zona vuggy silica. Mineral rutil terdapat dalam jumlah yang tidak signifikan namun konsisten terdapat dalam conto batuan.

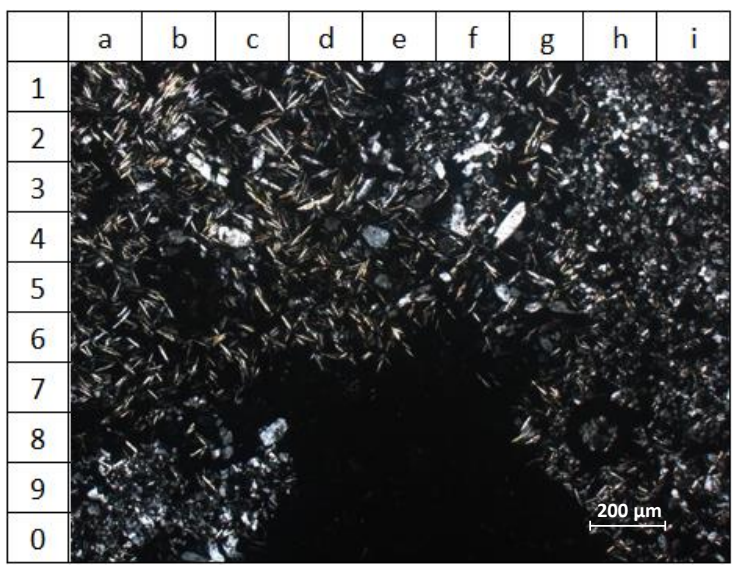

Gambar 7. Fotomikrograf sayatan tipis dengan perbesaran $200 \mu \mathrm{m}$

Ket.: alunit $=b 1$, mineral lempung $=h 1$, mineral opak= h3, kuarsa $=\mathrm{e} 4, v u g=$ rongga $=\mathrm{e} 8-\mathrm{e} 0$.

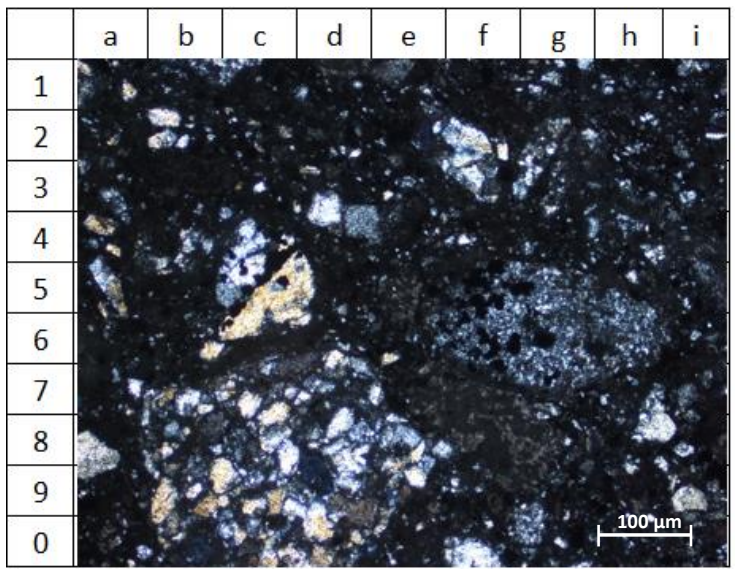

Gambar 8. Fotomikrograf sayatan tipis dengan perbesaran $100 \mu \mathrm{m}$

Ket: alunit $=f 2$, mineral lempung $=f 7-f 8$, mineral opak $=\mathrm{f6}-\mathrm{g} 6$, kuarsa $=\mathrm{d} 8$.

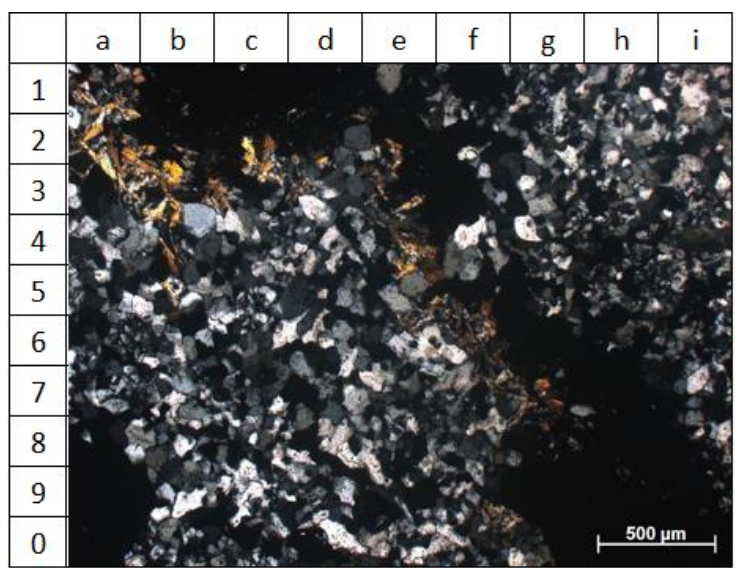

Gambar 9. Fotomikrograf sayatan tipis dengan perbesaran $500 \mu \mathrm{m}$

Ket.: alunit $=\mathrm{a} 1-\mathrm{a} 2$, mineral opak $=\mathrm{f} 6-\mathrm{g} 6$, kuarsa $=\mathrm{d} 5$ $\mathrm{d} 6, v u g=\mathrm{a} 8-\mathrm{a} 0$.

Sayatan batuan (Gambar 8) berasal dari titik bor APSD 1026 dengan kedalaman $120 \mathrm{~m}$ s.d. $121 \mathrm{~m}$ sedangkan sayatan batuan (Gambar 9) berasal dari titik bor APSD 1521 pada kedalaman 50,4 m s.d. $51,2 \mathrm{~m}$. Keduanya ditempati jenis batuan breksi polimik-monomik freatikfreatomagmatik yang ditandai dengan fragmen batuan yang telah mengalami ubahan kuat oleh jenis mineral lempung (ilit ?). Pada keseluruhan conto batuan terdapat fenokris mineral opak yang sebagian terlihat memiliki bentuk euhedralanhedral pada rekahan batuan dalam celah batuan/vug maupun tersebar pada tubuh batuan. Identifikasi terhadap jenis mineral lempung seperti illit, dikit dan pirofilit serta jenis mineral silika seperti kuarsa, kalsedon 
dan opal juga dilakukan menggunakan analisis $A S D$.

Secara megaskopis batuan telah mengalami ubahan dengan indikasi alterasi argilik berwarna abu-abu keputihan dengan tekstur batuan sugary, analisis $A S D$ menunjukkan karakteristik panjang gelombang mineral ilit-smektit yang mengalami interlayer satu sama lain dengan puncak gelombang minima $1.412,193 \mu \mathrm{m}$. Jenis mineral ilit-smektit memiliki rentang puncak minima pada $1.404 \mu \mathrm{m}$ s.d. $1.415 \mu \mathrm{m}$, selain itu penentuan jenis mineral ilit-smektit diketahui dari kenampakan garis full width at half maximum (FWHM) yang memiliki rentang pendek dan tidak simetris antara kedua minima, hal ini berarti mineral yang diamati memiliki kristalinitas yang sulit dibedakan antara jenis mineral ilit $\left[\mathrm{Al}_{2} \mathrm{Si}_{2} \mathrm{O}_{5}(\mathrm{OH})_{4}\right]$ atau smektit $\left[\mathrm{Na}_{0,2} \mathrm{Ca}_{0,1} \mathrm{Al}_{2} \mathrm{Si}_{4} \mathrm{O}_{10}(\mathrm{OH})_{2}\left(\mathrm{H}_{2} \mathrm{O}\right)_{10}\right]$. Batuan termasuk ke dalam jenis alterasi argilik (Gambar 10).

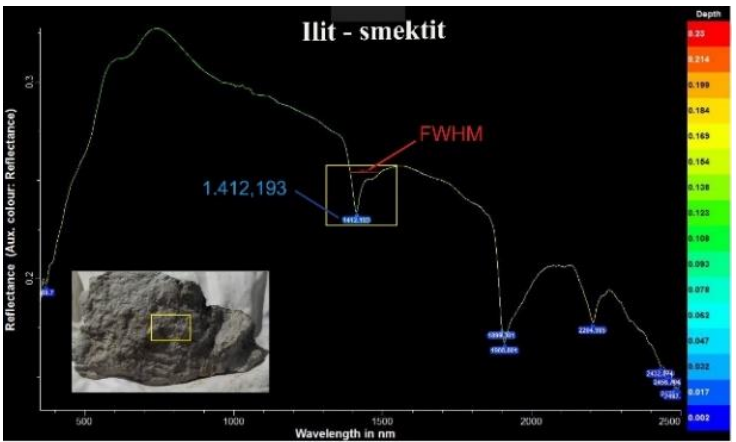

Gambar 10. Spektrum pembacaan ilitsmektit pada jenis batuan alterasi argilik

Secara megaskopis batuan termasuk kedalam alterasi argilik lanjut-argilik, conto batuan berwarna abu-abu keputihan dengan tekstur silica vuggy. Analisis $A S D$ menunjukkan kehadiran alunit $\left[\mathrm{KAl}_{3}\left(\mathrm{SO}_{4}\right)_{2}(\mathrm{OH})_{6}\right]$ dengan nilai spektrum $1.477,619 \mu \mathrm{m}$ sementara nilai ASD mineral ini berada pada rentang gelombang 1.425 $\mu \mathrm{m}$ s.d. $1.439 \mu \mathrm{m}$ dan $1.478 \mu \mathrm{m}$ s.d. 1.495 $\mu \mathrm{m}$ serta $2.168 \mu \mathrm{m}$ s.d. $2.173 \mu \mathrm{m}$ dan 2.205 $\mu \mathrm{m}$ s.d. $2.208 \mu \mathrm{m}$ bentuk kristal yang cukup baik yang ditunjukkan dengan rentang FWHM yang pendek antara kedua minima. Hematit berada pada nilai $840 \mu \mathrm{m}$, untuk rentang gelombang hematit $\left(\mathrm{Fe}_{2} \mathrm{O}_{3}\right)$ berada pada nilai $745 \mu \mathrm{m}$ s.d. $862 \mu \mathrm{m}$. Pirofilit $\left[\mathrm{Al}_{2} \mathrm{Si}_{4} \mathrm{O}_{10}(\mathrm{OH})_{2}\right]$ memiliki nilai spektrum $2.166,581 \mu \mathrm{m}$, sementara nilai spektrum $A S D$ untuk mineral ini berada pada rentang $1.392 \mu \mathrm{m}$ s.d. $1.396 \mu \mathrm{m}$ dan $2.166 \mu \mathrm{m}$ s.d. $2.168 \mu \mathrm{m}$ (Gambar 11).

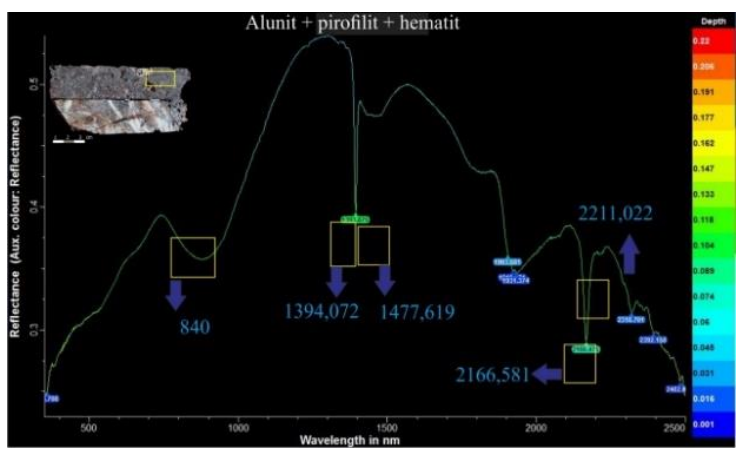

Gambar 11. Spektrum pembacaan mineral alunit, pirofilit dan hematit pada batuan argilik

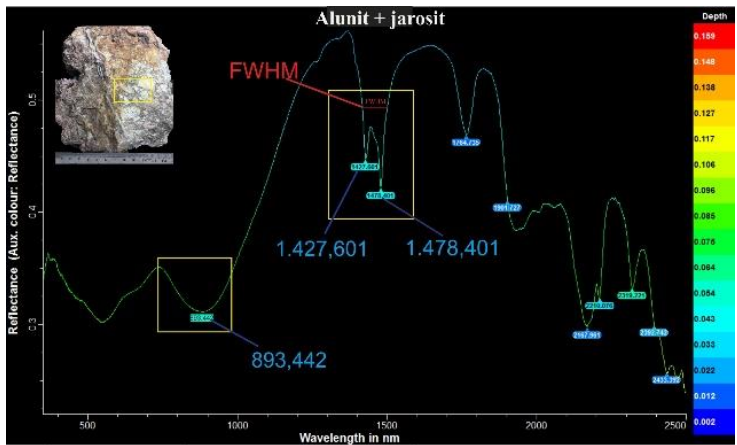

Gambar 12. Spektrum pembacaan mineral alunit serta jarosit

Batuan berwarna abu-abu kecoklatan yang memperlihatkan adanya tekstur wispy dan urat kuarsa. Berdasarkan analisis $A S D$, di sekitar mineral silika dan jarosit $\mathrm{KFe}^{3+}{ }_{3}(\mathrm{OH})_{6}\left(\mathrm{SO}_{4}\right)_{2}$ juga terdapat mineral alunit $\left[\mathrm{KAl}_{3}\left(\mathrm{SO}_{4}\right)_{2}(\mathrm{OH})_{6}\right]$ dengan bentuk kristal yang cukup baik yang ditunjukkan dengan rentang $F W H M$ yang pendek antara kedua minima. Mineral alunit diidentifikasi memiliki gelombang doublet pada nilai gelombang $A S D$ 1.427,601 $\mu \mathrm{m}$ s.d. $1.478,401 \mu \mathrm{m}$, nilai $A S D$ mineral ini berada pada rentang gelombang $1.425 \mu \mathrm{m}$ s.d. $1.439 \mu \mathrm{m}$ serta $2.205 \mu \mathrm{m}$ s.d. $2.208 \mu \mathrm{m}$ (Hauff, 2004). Batuan termasuk ke dalam alterasi argilik lanjut (Gambar 12). 
Zona mineralisasi yang berkembang pada daerah penelitian berdasarkan hasil interpretasi dikontrol oleh struktur yang berarah utara sampai timurlaut - selatan baratdaya dan merupakan bukaan akibat struktur utama Sesar Sumatera berarah utara sampai baratlaut - tenggara (Davies, 2002). Tahapan mineralisasi yang berlangsung pada daerah penelitian dibagi menjadi beberapa tahapan yang berbeda:

- Tahap pra-sulfidasi

Sulfidasi dari mineral pembawa besi (Fe) oleh fluida hidrotermal (vapor phase) sehingga membentuk mineral pirit yang hadir berikatan dengan unsur sulfur yang terdapat di batuan. Pirit berukuran halus dan membentuk klaster yang berbentuk prismatic-hexagonal atau juga hadir tersebar merata pada batuan sebagai mineral aksesoris hasil sulfidasi.

- Tahap mineralisasi Au

Larutan fluida magmatik yang kaya akan logam mengendapkan mineral enargit, tennantit, tetrahedrit, kovelit, pirit dan emas yang mengisi vuggy. Berdasarkan pengamatan mikroskopis sebagian enargit terbentuk lebih dahulu yang diikuti dengan pembentukan pirit, mineral tetrahedrit, sfalerit maupun kovelit, demikian pula dengan butiran emas yang berukuran sub mikron dan terikat di dalam mineral sulfida seperti pirit, enargit dan tetrahedrit (Sutopo et al, 2013 dan Saing et al, 2016).

Pirit yang hadir pada tepi celah batuan vug, rekahan maupun yang tersebar secara klaster yang menunjukkan bentuk dan karakteristik yang berbedabeda mengindikasikan tahapan pembentukan pirit yang berbeda-beda pula.

- Tahap post mineralisasi Au

Fase akhir dari aktifitas hidrotermal, membentuk pirit dengan bentuk kristal yang baik dan sempurna, yang mengindikasikan proses pendinginan berlangsung lambat atau pada suhu pembentukan yang relatif stabil sehingga kristalisasi berlangsung dengan baik.

Jenis mineral sulfida yang hadir pada daerah penelitian diketahui melalui pengamatan makroskopis dan analisis mineragrafi sayatan poles dan analisis SEM-EDS. Pemilihan conto untuk analisis mineragrafi sayatan poles berdasarkan pada hasil analisis Atomic Absorption Spectrometry (AAS) yaitu dengan menggunakan nilai kandungan $\mathrm{Au}>0,6$ ppm sebagai batas bawah nilai ekonomis material bijih penambangan.

Analisis mineragrafi dilakukan pada 25 conto sayatan poles bertujuan untuk mengkonfrimasi keberadaan mineralmineral sulfida dan teksturnya secara mikroskopik sehingga pendekatan terhadap paragenesa mineral sulfida dapat dilakukan.

Identifikasi terhadap mineral sulfida dan oksida yang ditemukan melalui pengamatan terhadap sayatan conto batuan, antara lain:

- Pirit $\left(\mathrm{FeS}_{2}\right)$; secara umum berwarna kuning hingga krem pucat, memiliki relief tinggi, berukuran antara $0,005 \mathrm{~mm}$ s.d. 0,2 mm, isotropik, daya pantul kuat, bentuk kubik kristalin, mengisi rekahan dan dijumpai sebagai butiran tunggal yang tersebar, selain memiliki bentuk kristal kubik yang baik, pirit di sebagian conto menunjukkan tekstur broken dan diganti menjadi mineral lainnya (Gambar 13).

- Enargit-luzonit $\left(\mathrm{Cu}_{3} \mathrm{AsS}_{4}\right)$; berwarna abu-abu kecoklatan hingga kemerahan, relief sedang, daya pantul lemahsedang, bireflektan sedang, berukuran $0,02 \mathrm{~mm}$ s.d. $0,35 \mathrm{~mm}$, anisotropik kuat, menunjukkan tekstur intergrowth, dijumpai sebagai butiran tunggal maupun berikatan dengan pirit dan tetrahedrit (Gambar 14). 
- Tetrahedrit $\left.\left[(\mathrm{Cu}, \mathrm{Fe})_{12} \mathrm{Sb}_{4} \mathrm{~S}_{13}\right)\right]$; berwarna abu-abu kebiruan, daya pantul lemahsedang, relief sedang, berukuran 0,02 $\mathrm{mm}$ s.d. 0,5 mm, isotropik, dijumpai berikatan dengan pirit dan enargitluzonit serta mengisi rongga-rongga pada pirit atau mineral silikat (Gambar 13).

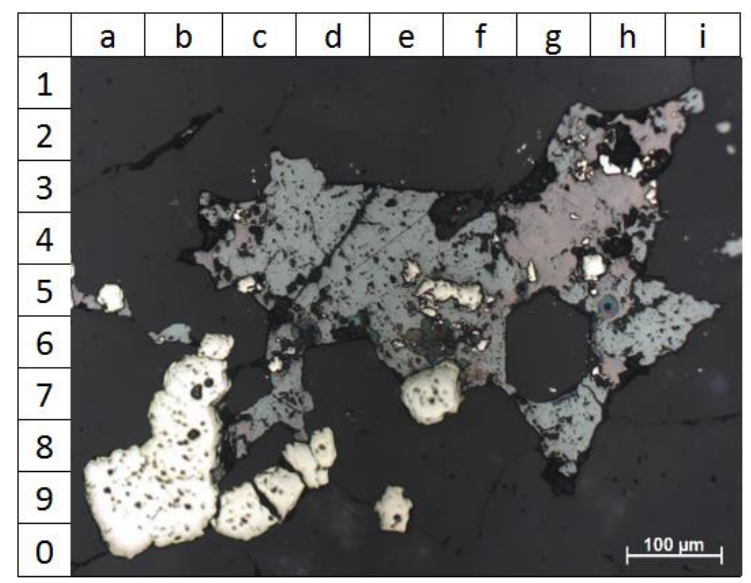

Gambar 13. Fotomikrograf sayatan poles Ket.: enargit-luzonit $=\mathrm{g} 3-\mathrm{g} 4$, pirit= $\mathrm{b} 8-\mathrm{b0}, \quad \mathrm{td}=$ tetrahedrit= $\mathrm{c} 4-\mathrm{e} 4$, kovelit $=\mathrm{d} 6$.

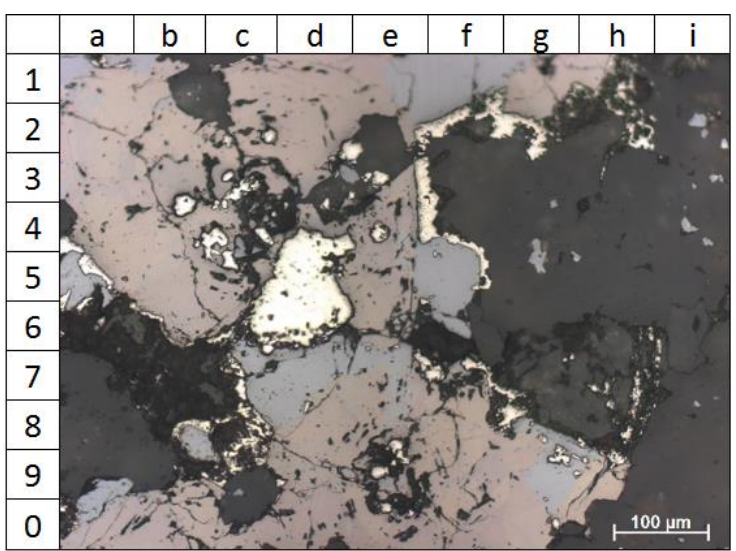

Gambar 14. Fotomikrograf sayatan poles Ket.: anatas $=\mathrm{g} 4-\mathrm{g} 5$, enargit $=\mathrm{f5}$ luzonit= f8-f0, pirit= d4-d5, kovelit= d5-e5.

- Kovelit (CuS); warna biru, relief rendah, berukuran <0,01 mm, anisotropik kuat, daya pantul sedang, dijumpai menggantikan tetrahedrit (Gambar 16).

- Famatinit $\left(\mathrm{Cu}_{3} \mathrm{SbS}_{4}\right)$; berwarna merah muda kecoklatan, relief sedang, daya pantul lemah-sedang, bireflektan sedang, anisotropik kuat, berukuran $0,01 \mathrm{~mm}$ s.d. 0,4 mm, dijumpai sebagai butiran tunggal maupun berikatan dengan pirit (Gambar 15).

- Stibnit $\left(\mathrm{Sb}_{2} \mathrm{~S}_{3}\right)$; berwarna abu-abu terang, relief rendah, daya pantul sedang, berukuran 0,006 mm s.d. 0,07 $\mathrm{mm}$, anisotropik kuat, menunjukkan tekstur intergrowth dengan famatinit (Gambar 15).

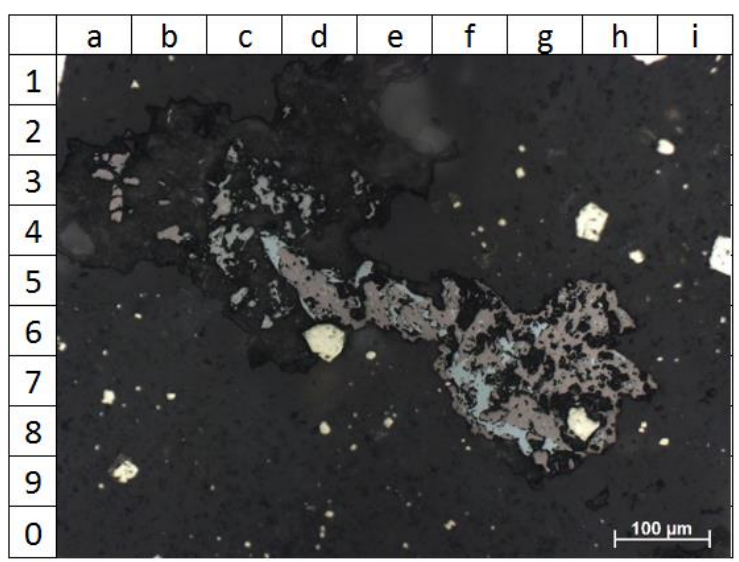

Gambar 15. Fotomikrograf sayatan poles Ket.: pirit= d6, stibnit= f7, g8, famatinit= d5.

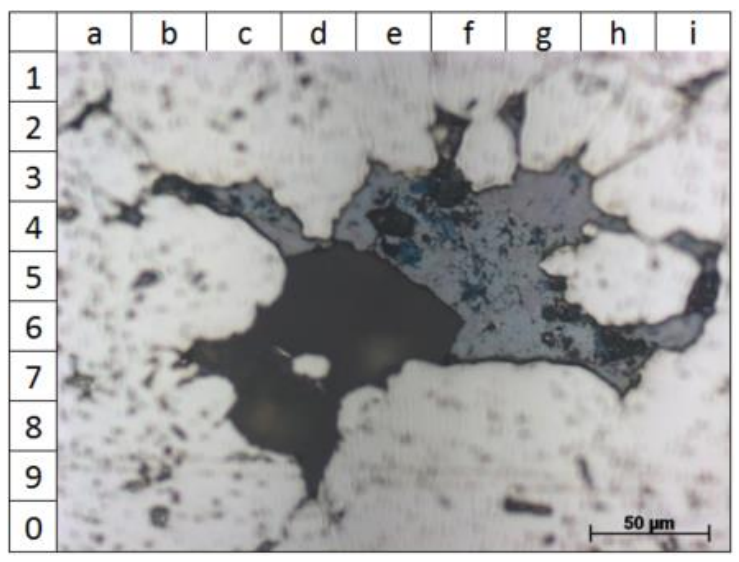

Gambar 16. Fotomikrograf sayatan poles Ket.: enargit-luzonit $=\mathrm{g} 3-\mathrm{g} 4$, pirit $=\mathrm{a} 1-\mathrm{i} 1$, tetrahedrit= $g 6$, i6, kovelit= e5, $f 4$.

- Tennantit $\left.\left[(\mathrm{Cu}, \mathrm{Fe})_{12}\right] \mathrm{As}_{4} \mathrm{~S}_{13}\right] ;$ abu-abu kecoklatan agak kebiruan, relief sedang, berukuran $0,01 \mathrm{~mm}$ s.d $0,11 \mathrm{~mm}$, isotropik, dijumpai sebagai butiran tunggal (Gambar 17). 


\section{MAKALAH ILMIAH}

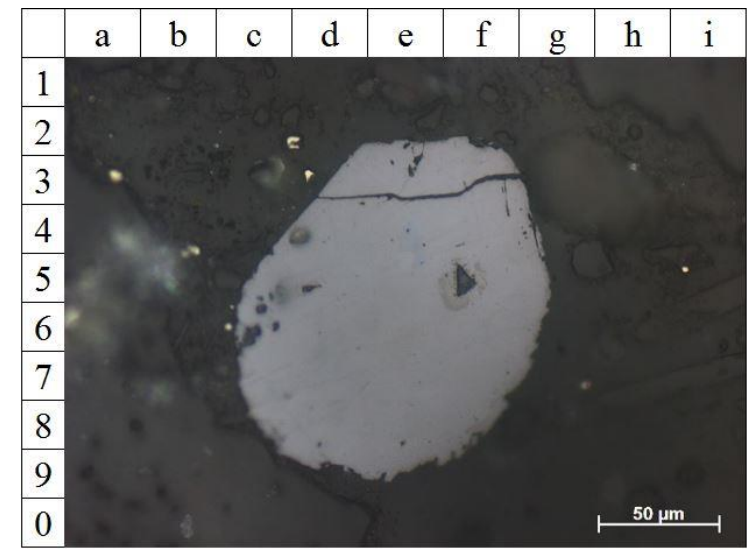

Gambar 17. Fotomikrograf sayatan poles Ket.: inklusi kovelit dan pirit pada enargit c6, f5, pirit= a3, tennantit= e4 (solid solution berwarna kebiruan), inklusi kovelit dan pirit dalam rekahan= d3-f3).

Pengujian SEM dilakukan dengan JEOL JED-2200 Series yang dilengkapi dengan perangkat Energy Dispersive X-Ray Spectroscopy (EDS) untuk analisis komposisi kimia. Analisis ini dikerjakan pada Laboratorium Tekmira dan Laboratorium Universitas Padjadjaran, Bandung. Penggunaan mikroskop elektron mengkonfirmasi jenis mineral alterasi, sulfida dan mineral oksida dalam batuan yang terdapat pada daerah penelitian, selain itu tekstur dan karakter fisik dari mineral dapat diamati lebih baik.
Analisis SEM-EDS, untuk conto sayatan dengan nomor conto D.8001957 yang berasal dari titik bor APSD 1673 diambil dari kedalaman $22 \mathrm{~m}$ s.d. $23 \mathrm{~m}$ (Gambar 18A dan 18B) menunjukkan mineral pirit yang diperlihatkan dengan struktur permukaan pada garis kuning $(z)$ berwarna abu-abu terang berbentuk prismatik kubik dan sebagian berbentuk irregular di dalam celah/vug atau pada veinlet dengan ukuran yang lebih besar. Penentuan jenis mineral didasarkan pada grafik spektrum EDS dengan presipitasi $X$-Ray yang menunjukkan persentase kandungan unsur mineral yang terdapat dalam conto batuan (Gambar 19). Mineral pirit terindikasi dari hasil presipitasi $x$-ray untuk kandungan $\mathrm{Fe}$ sebesar $26,38 \%$ dan S sebesar $20,06 \%$, sedangkan indikasi mineral alunit pada garis hijau (y) terindikasi dari nilai presipitasi $X$-Ray untuk O sebesar $13,84 \%$ dan $\mathrm{Al}$ sebesar $3,34 \%$ sementara untuk mineral yang ditunjukkan dengan kode $x$ terindikasi sebagai kuarsa yang memperlihatkan struktur mosaic serta memiliki nilai presipitasi untuk kandungan Si sebesar 33,38\%. Struktur mikro pada (Gambar 18b) memperlihatkan mineral kuarsa berbentuk prismatik sedangkan alunit berbentuk tabular yang mengambang diatas kuarsa.
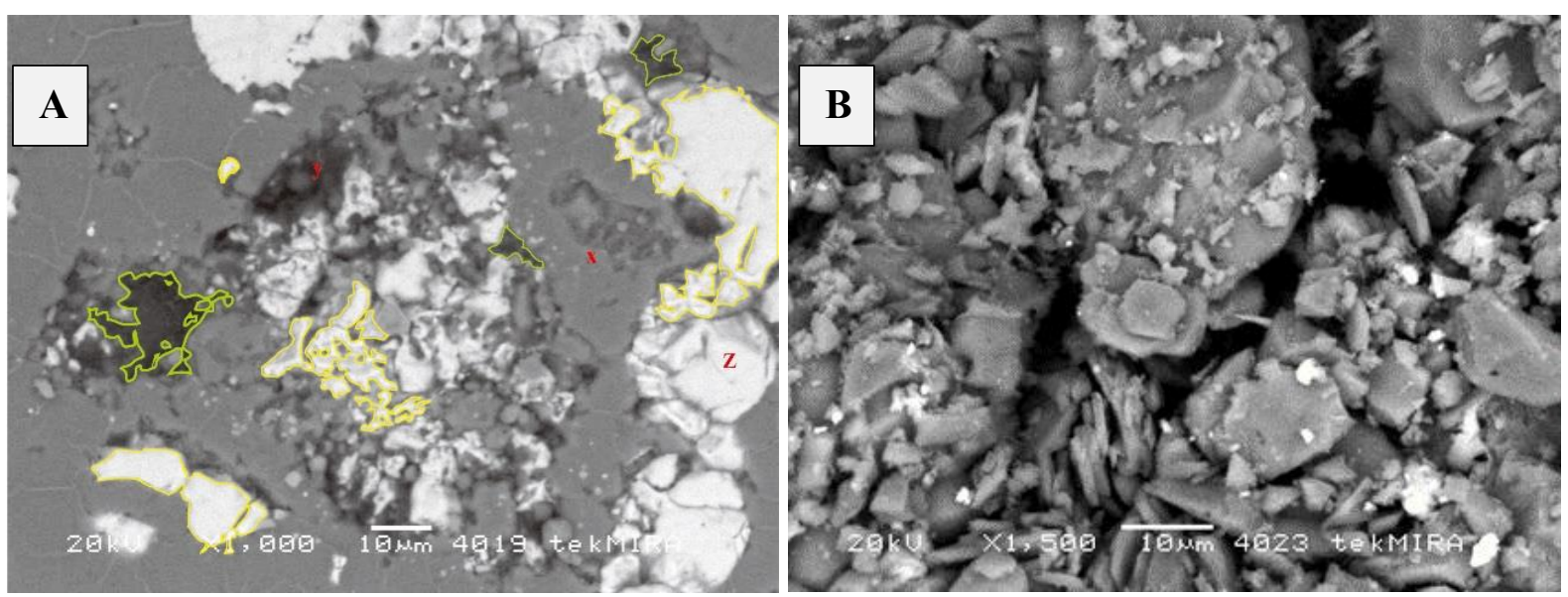

Gambar 18 Struktur permukaan perbesaran conto1000x menunjukkan mineral pirit (z), alunit (y) dan kuarsa (x) (A). Struktur mikro pada perbesaran conto 1500x (B) 


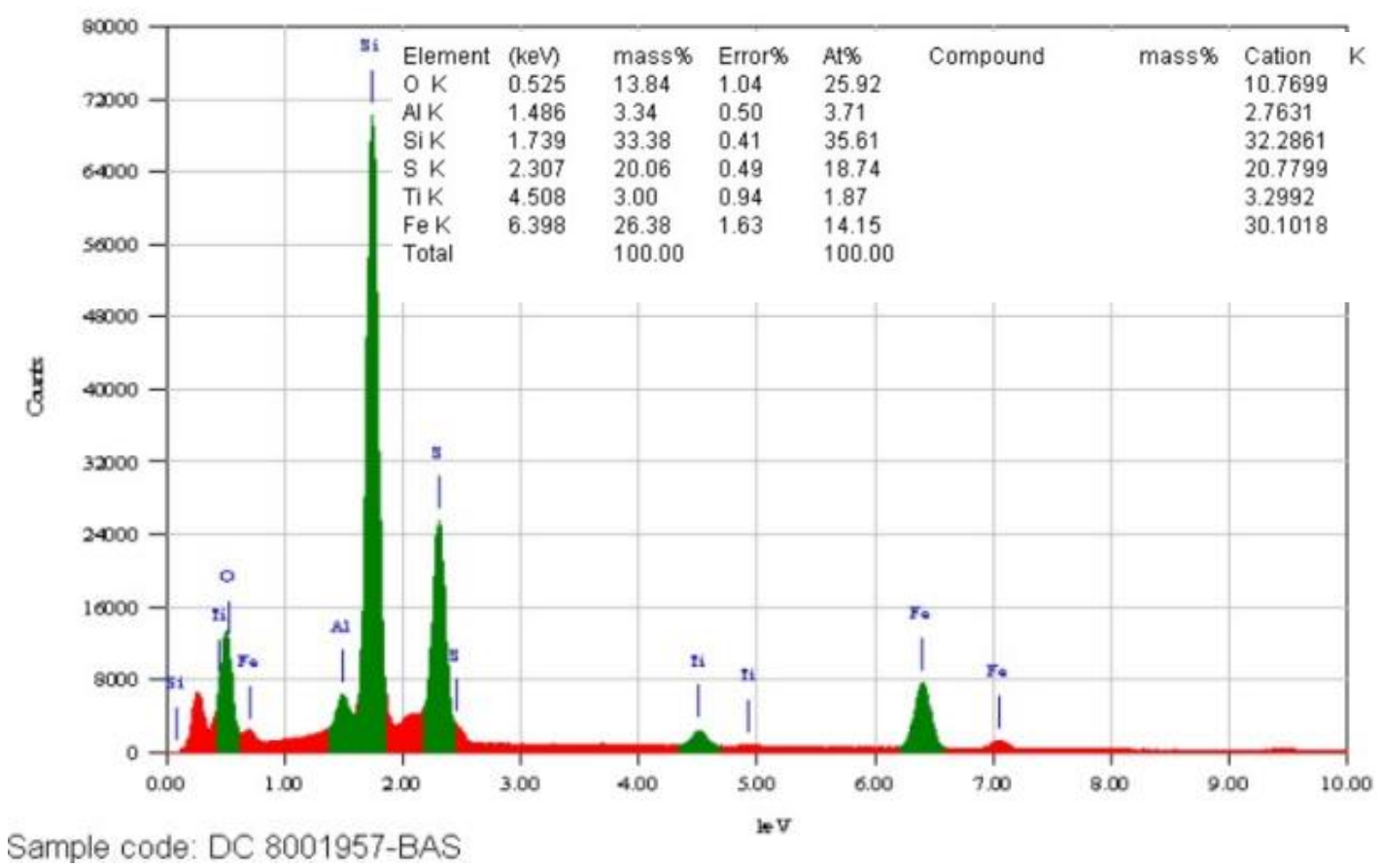

Gambar 19. Grafik EDS conto D.8001957 dengan spektrum presipitasi X-Ray serta persentase unsur yang terdapat dalam contoconto batuan

Hasil analisis SEM-EDS, untuk conto sayatan dengan nomor conto D.1674052 yang berasal dari titik bor APSD 1521 diambil dari kedalaman $92 \mathrm{~m}$ s.d. $93 \mathrm{~m}$ (Gambar 20A dan 20B), menunjukkan mineral berwarna abu-abu gelap dengan bentuk kristal kubik dan di beberapa bagian memiliki tekstur broken adalah mineral pirit pada garis kuning ( $\mathrm{z})$, mineral enargitluzonit $(x)$ memiliki warna abu-abu terang dengan struktur smooth dan terdapat adanya inklusi kristal pirit di dalamnya. Perak pada lingkaran berwarna magenta (z) dan tennantit pada lingkaran merah (h) terdapat diantara pirit serta enargit-luzonit namun dikelilingi oleh mineral hematit yang terdapat di sekitar mineral atau terlihat di dalam rekahan batuan.

Analisis SEM-EDS, untuk conto sayatan dengan nomor conto D.3112436 yang diambil dari titik bor APSD. 1500 kedalaman $50,4 \mathrm{~m}$ s.d. $51,2 \mathrm{~m}$ (Gambar $21 \mathrm{~A}$ dan 21B), menunjukkan mineral yang berwarna abu-abu gelap memiliki tekstur broken dan kristal kubik adalah mineral pirit $\left(\mathrm{FeS}_{2}\right)$ pada lingkaran garis kuning ( $\left.\mathrm{z}\right)$, mineral enargit-luzonit (y) memiliki warna abu-abu terang dengan struktur smooth namun terdapat adanya inklusi kristal pirit. Hematit pada lingkaran oranye $(m)$ terdapat diantara pirit dan enargit-luzonit di bagian tepi dari mineral tersebut. Kuarsa pada lingkaran garis biru $(\mathrm{x})$ dengan butiran yang besar terdapat dengan warna abu-abu gelap memiliki bentuk kristal euhedral namun di dalamnya terdapat inklusi pirit.

Penentuan jenis mineral didasarkan pada grafik spektrum EDS dengan presipitasi $X$ ray yang menunjukkan persentase kandungan unsur mineral yang terdapat dalam conto batuan (Gambar 22). Mineral pirit (z) terindikasi dari hasil presipitasi $X$ ray untuk kandungan Fe sebesar 3,95\% dan $S$ sebesar $21,43 \%$, sedangkan indikasi mineral enargit $(y)$ terindikasi dari nilai presipitasi $X$-ray untuk Cu sebesar 42,29\% dan As sebesar 13,98\% sementara untuk mineral yang ditunjukkan dengan kode $x$ terindikasi sebagai kuarsa yang memperlihatkan struktur mosaic serta memiliki nilai presipitasi untuk kandungan $\mathrm{Si}$ sebesar 10,75\%, kehadiran alunit terindikasi dengan kehadiran unsur $\mathrm{Al}$ sebesar $1,12 \%$, sedangkan hematit $(m)$ diindikasikan dengan kehadiran unsur $\mathrm{Fe}$ sebesar $3,95 \%$ dan O sebesar $6,50 \%$. 


\section{MAKALAH ILMIAH}
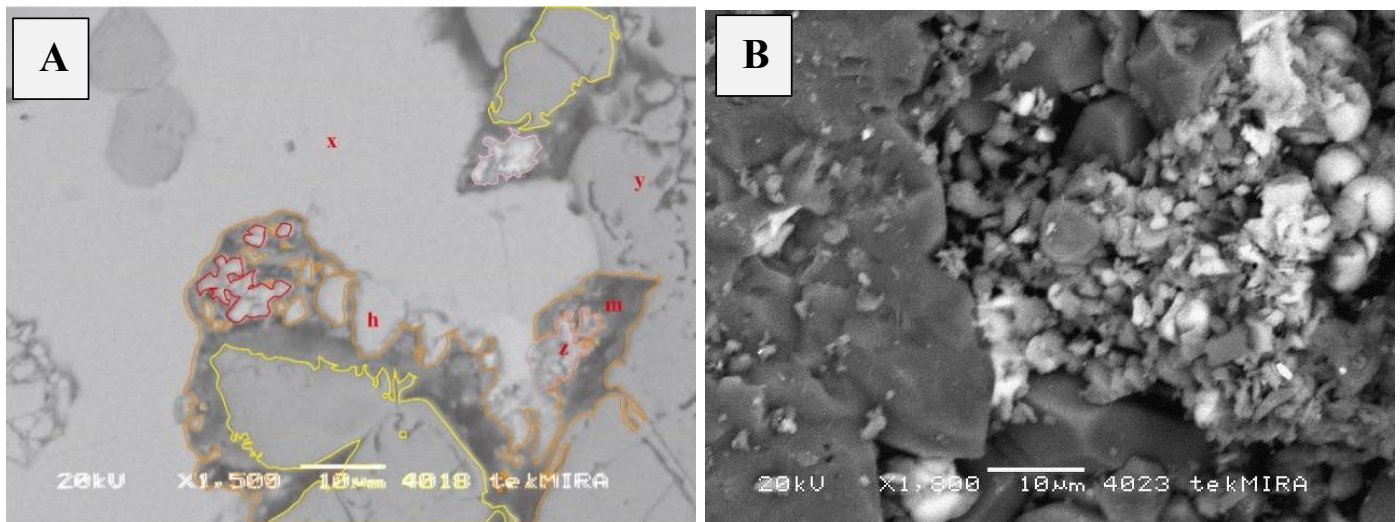

Gambar 20. Struktur permukaan dengan perbesaran conto 1500x dengan indikasi mineral pirit $(y)$, tennantit $(h)$, perak $(z)$, hematit $(m)$ dan enargit-luzonit $(x)(A)$. Struktur mikro pada perbesaran conto 1800x (B)
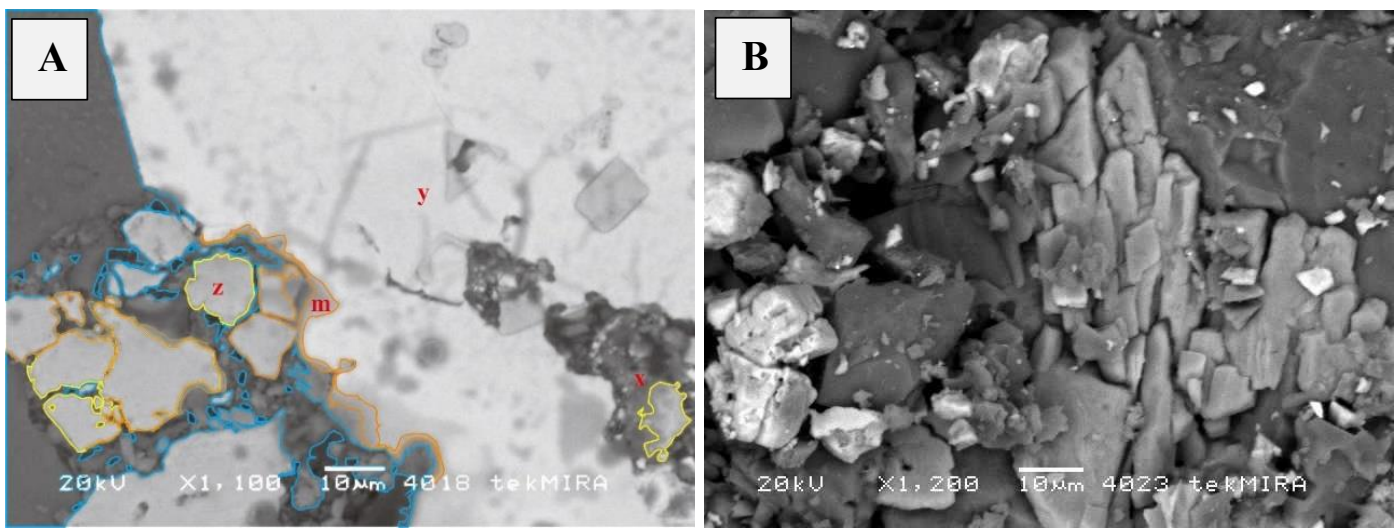

Gambar 21. Struktur permukaan dengan perbesaran 1100x dengan indikasi mineral pirit (z/garis kuning), enargit-luzonit (y), hematit (m/garis oranye) dan kuarsa (x) (A). Struktur mikro pada perbesaran conto $1200 x(B)$

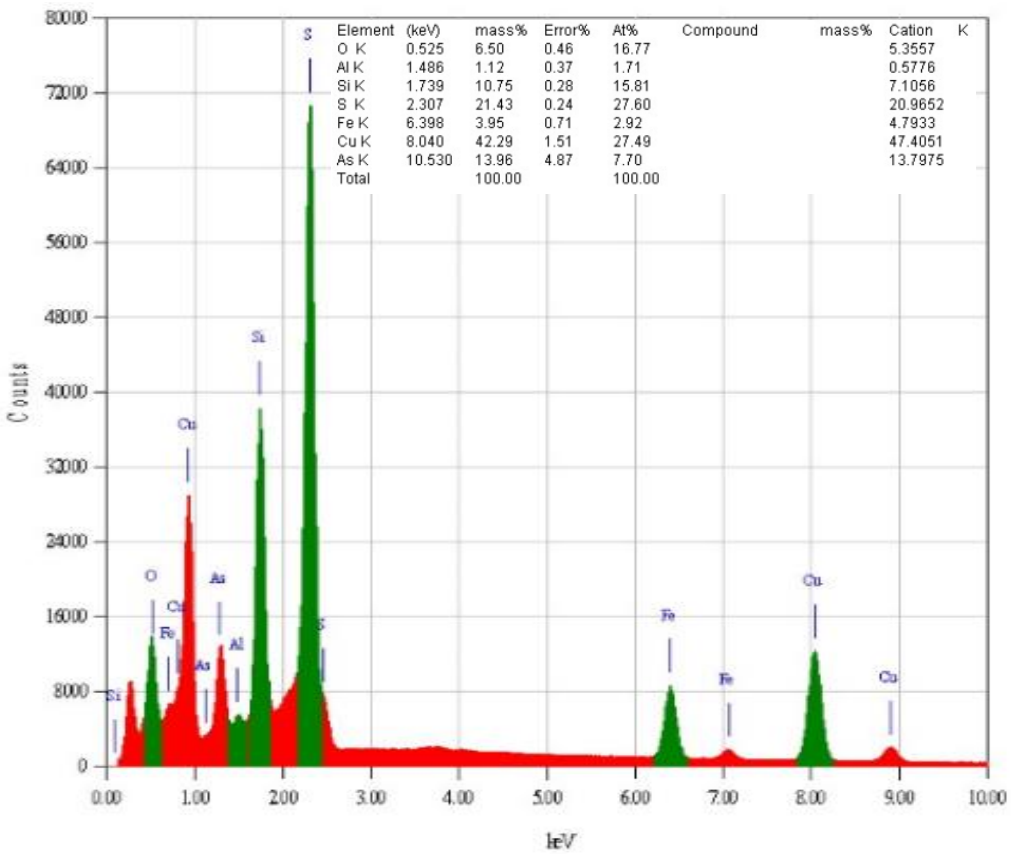

Gambar 22. Grafik EDS dengan spektrum presipitasi $X$-Ray conto D.3112436 yang menunjukkan persentase unsur yang terdapat dalam conto batuan 
Paragenesa mineral sulfida daerah penelitian diawali dengan pembentukan mineral pirit, kemudian pirit mengalami replacement menjadi enargit-luzonit, dalam persentase yang kecil enargit-luzonit sebagian berubah menjadi tennatit. Pirit, arsenopirit serta sfalerit yang memiliki bentuk kristal kubik mengisi mineral enargit-luzonit dalam bentuk inklusi atau tersebar secara klaster di dalam tubuh batuan dan rekahan atau celah/vug yang hadir pada fase akhir. Kemudian dilanjutkan dengan kehadiran mineral tetrahedrit dan kovelit yang mengisi rekahan antar pirit atau hadir sebagai inklusi dalam enargit-luzonit. Dengan demikian, diketahui bahwa urut-urutan pembentukan mineral sulfida pada daerah penelitian adalah dimulai dari pembentukan pirit, kemudian enargitluzonit, tenantit, tetrahedrit dan kovelit bersamaan dengan pengayaan butiran emas-perak serta diakhiri dengan pembentukan pirit yang memiliki butiran kristal yang baik dan sempurna (Tabel 1).

Tabel 1. Urutan paragenesa mineral sulfida

\begin{tabular}{|c|c|}
\hline \multicolumn{2}{|c|}{ Tahapan pembentukan mineral sulfida } \\
\hline Pirit & - \\
Enargit-luzonit & - \\
Tennantit & \\
Tetrahedrit-kovelit & \\
(emas-perak) & \\
Pirit & \\
(kristal sempurna) & \\
\hline
\end{tabular}

\section{Hubungan Alterasi dan Mineralisasi}

Korelasi antara mineralisasi terhadap alterasi diwakili dengan hubungan antara kadar Au (ppm), Ag (ppm), Cu (ppm) dan SxS ( $p p m)$ terhadap zona alterasi yang ada pada deposit Ramba Joring, keseluruhan nilai kadar yang digunakan berasal dari 44 lubang bor dengan jumlah data kadar sebanyak 5.222 conto. Grafik pada Gambar 23 menunjukkan bahwa jenis alterasi berkaitan erat dengan mineralisasi yang terjadi pada daerah penelitian.
Mineralisasi yang baik dicirikan dengan kumpulan nilai kadar logam berharga yang semakin besar yang dibawa oleh mineral sulfida. Mineralisasi kuat terjadi pada jenis alterasi silisifikasi dan semakin berkurang pada alterasi argilik dan menghilang pada alterasi propilitik, yang berkorelasi positif terhadap kandungan logam berharga yang terdapat pada deposit tersebut.

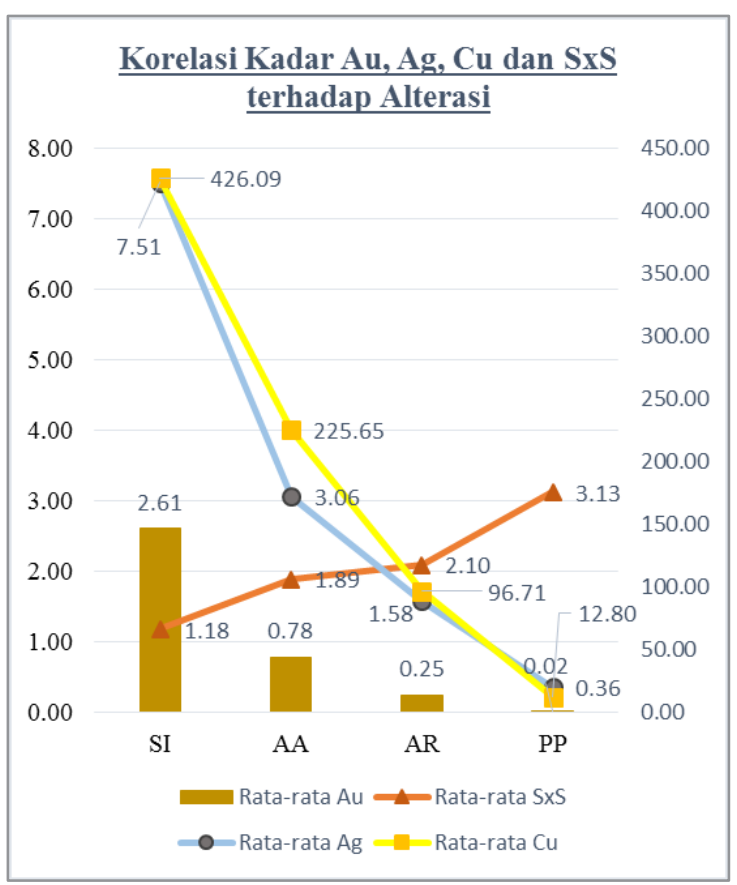

Gambar 23. Grafik korelasi kadar $\mathrm{Au}, \mathrm{Ag}$, $\mathrm{Cu}$ dan SxS (kadar dalam ppm) dengan alterasi daerah penelitian

\section{DISKUSI}

Struktur geologi yang hadir pada daerah penelitian merupakan salah satu faktor penentu terbentuknya deposit Tambang emas Martabe, selain jenis batuan yang memiliki permeabillitas yang baik yaitu andesit hornblende dan batuan breksi polimik-monomik. Struktur geologi merupakan pembentuk jalur keluarnya larutan hidrotermal yang mengalterasi kedua jenis batuan yang ada. Larutan hidrotermal yang bersifat asam menyebabkan terbentuknya jenis alterasi silisifikasi, argillik lanjut, argilik serta propilitik dengan mineral-mineral ubahan seperti alunit, dikit, kaolinit, jarosit, pirofilit, illit-smektit dan mineral sulfida seperti pirit, enargit-luzonit, famatinit, tennantit, 
tetrahedrit, sfalerit, arsenopirit dan kovelit yang menjadi penciri dari endapan epitermal sistem sulfidasi tinggi. Perubahan jenis alterasi dari dalam ke luar merupakan indikasi dari perubahan temperatur serta tingkat keasaman batuan yang mengalami alterasi.

Pembentukan mineral-mineral sulfida terutama pada jenis alterasi silisifikasi dan argilik lanjut diikuti dengan kehadiran emas dan perak dalam bentuk inklusi pada mineral pirit dengan ukuran submikron, merupakan hal yang menarik untuk ditelaah lebih lanjut, khususnya terhadap studi paragenesa mineral sulfida di daerah penelitian.

\section{KESIMPULAN}

Jenis batuan yang terdapat pada daerah penelitian yaitu andesit hornblende dan breksi polimik-monomik, mendukung terbentuk dan berkembangnya alterasi hidrotermal. urutan pembentukan kedua jenis batuan didahului oleh adanya intrusi lava andesit membentuk kompleks dome kemudian diterobos oleh satuan breksi polimik-monomik.

Zonasi alterasi yang terdapat pada daerah penelitian terdiri atas 4 zonasi, yaitu zona silisifikasi, argilik lanjut, argilik dan propilitik. Mineralisasi yang ditemukan adalah mineral pirit, enargit-luzonit, tenantit, kovelit, tetrahedrit, dan inklusi perak, selain sulfida ditemukan adanya mineral oksida hematit dan goetit. Paragenesa mineral bijih setidaknya melalui 3 tahap yaitu (a) pra-sulfidasi pembentukan pirit, (b) mineralisasi enargit, kovelit, tetrahedrit bersama dengan emas-perak, (c) pembentukan pirit dengan kristal yang baik. Keberadaan jenis alterasi dengan kandungan $\mathrm{Au}, \mathrm{Cu}$ dan SxS (sulfide sulphur) memiliki korelasi positif, jenis alterasi silisifikasi memiliki kandungan mineral berharga yang paling banyak dari semua jenis alterasi yang terdapat pada daerah penelitian.

\section{UCAPAN TERIMA KASIH}

Pihak PT Agincourt Resources, tim Departemen Mine Geology, Fakultas Teknik Geologi Unpad dan Laboratorium Tekmira Bandung.

\section{DAFTAR PUSTAKA}

Apsden, J.A., Stephenson, B., Cameron, N.R. 1982a. Tectonic Map of Northern Sumatra $(1: 1,500,000)$. Directorate of Overseas Surveys.

Corbett, J.G., dan Leach, T.M., 1998, Southwest Pacific Rim gold-copper systems: Structure, alteration, mineralization: Society of Economic Geologist Special Publication, v.6, p. 237.

Davies, B., 2002. Report on the structural review of the Martabe project, Newmont Horas Nauli, internal memorandum, 5 p. Tidak terpublikasi.

De Smet, M.E.M and Barber, A.J., 2005, Tertiary stratigraphy. In: Sumatra, Geology, Resources and Tectonic Evolution (eds) Barber, A.J., Crow, M.J., and Milsom, J.. Geological Society, London, Memoirs 2005; v. 31; p. 86-97.

Hauff, Phoebe, 2004. An overview of VISNIR SWIR Field Spectroscopy as Applied to Precious Metal Exploration. Spectral International INC.

Hedenquist JW, Arribas A Jr, Reynolds TJ.1998. Evolution of an intrusioncentered hydrothermal system: Far Southeast Lepanto porphyry and epithermal $\mathrm{Cu}-\mathrm{Au}$ deposits, Philippines. Economic Geology, 93 (4) pp 373-404.

Henley, R.W., and Ellis, A.J., 1983. Geothermal Systems, Ancient and Modern. Earth Science Reviews, v.19, p. 1-50.

Pirajno, F. 2009. Hydrothermal Processes and Mineral Systems. Perth: Springer 


\section{MAKALAH ILMIAH}

Saing, S, \& Ryohei, T., Imai, A. (2016). Fluid Inclusion and Stable Isotope Study at the Southeastern Martabe Deposit: Purnama, Barani and Horas Ore Bodies, North Sumatra, Indonesia. The Society of Resource Geology.

Sutopo, B, Brian K. Levet, and Gemmel Bruce J. (2013). Characteristics of Sub-Microscopic Gold and Trace Element Geochemistry of Enargite/Luzonite in the Martabe High Sulfidation Epithermal Deposits, North Sumatra, Indonesia.
Stoffregen, R., 1987, Genesis of acid sulfate alteration and $\mathrm{Au}-\mathrm{Cu}$ mineralization at Summitville: Economic Geology, v. 82, p. 15751591.

Thompson, A.J.B, Thompson J.F.C. 1996 Atlas of Alteration. Geological Association of Canada - Association Geologique du Canada Division des gites mineraux. Mineral Deposit Division-GAC.

$\begin{array}{ll}\text { Diterima } & : \text { 1 Maret } 2019 \\ \text { Direvisi } & : \text { 6 Mei } 2019 \\ \text { Disetujui } & : \text { 19 Agustus } 2019\end{array}$

